\title{
The Constitutional Right to Counsel in Tax Investigations
}

The Supreme Court in Escobedo v. Illinois ${ }^{1}$ extended the right to counsel under the sixth amendment, as applied to the states by the fourteenth amendment "due process" clause, to the pre-indictment proceedings in a state homicide case. This comment explores Escobedo's potential for expansion ${ }^{2}$ to the pre-indictment stage of criminal prosecutions for alleged violations of a statute enforced by an administrative agency. ${ }^{3}$ This necessitates a re-examination of decisions holding that there is no constitutional right to counsel in administrative investigations $^{4}$ and that the subject of such an investigation who subsequently

1378 U.S. 478 (1964).

2 The phrase is from Lockhart, Kamisar \& Choper, Constrtutional Criminal ProGEDURE 96 (1964).

3 See Enker \& Elsen, Counsel for the Suspect, 49 Mins. L. REv. 47, 75-77 (1964), for the only other discussion of this question.

4 Anonymous v. Baker, 360 U.S. 287 (1959); In re Groban, 352 U.S. 330 (1957); United States ex rel. Bilokumsky v. Tod, 263 U.S. 149 (1923); Low Wah Suey v. Backus, 225 U.S. 460 (1912); Bowles v. Baer, 142 F.2d 787 (7th Cir. 1944). See generally 1 Davis, AdminisTRATIVE LAW \& 8.10 (1958); Gordon, Right to Counsel in Immigration Proceedings, 45 MinN. L. REv. 875, 876, 880-83 (1961); Withrow, Investigatory Powers of the Federal Trade Commission-Constitutional and Statutory Limitations, 24 FED. B.J. 456, 470-74 (1964); Note, Representation by Counsel in Administrative Proceedings, 58 Colum. L. REv. 395, 401-03 (1958); Note, The Right to Assistance of Counsel in Administrative Proceedings, 34 NOTRE DAME LAw. 90 (1958).

There is conflicting authority on whether the statutory right to counsel under the federal Administrative Procedure Act, 60 Stat. 240 (1946), 5 U.S.C. \& 1005(a) (1964), exists in administrative investigations. Compare United States v. Steel, 238 F. Supp. 575 (S.D.N.Y. 1965), with Wanderer v. Kaplan, 1962 Trade Cas. 77159 (D.D.C. 1962). See also 1 Davis, op. cit. supra; Gordon, supra; Hill, Investigative Powers and Techniques of the Federal Power Commission, 31 J.B.A.D.C. 193 (1964); Murchison, Rights of Persons Compelled to Appear in Federal Agency Investigatorial Hearings, 62 MIcH. L. REv. 485 (1964); Rosenblum \& Silverstein, Investigations under LandrumGriffin, 49 GEo. L.J. 257 (1960); Withrow, supra; Wolfe, The Right To Counsel in an Administrative Investigatory Proceeding, 16 AdmIN. L. REv. 325 (1964); Note, supra, 58 Colum. L. Rev. 395 (1958). Nevertheless, Senator Dirksen, in introducing a bill which would expressly extend the statutory right to counsel to agency investigations, assumed that "in the present law ... [the] right to counsel does not extend to agency investigations . . . ." 111 Cong. Rec. 3983 (daily ed. March 4, 1965).

An anomaly of the present federal statutory right to counsel is that it is limited to "any person compelled to appear." Administrative Procedure Act, 60 Stat. 240 (1946), 5 U.S.C. $\$ 1005$ (a) (1964). The Administrative Conference recommended that the statute be amended to accord the same right to persons who appear voluntarily. Senate Comm. on the Judiciary, Selected Reports of the Administrative Conference of the United States, S. Doc. No. 24, 88th Cong., Ist Sess. 223 (1963). This recommendation was incorporated in 
becomes a criminal defendant need not have been apprised of the privilege against self-incrimination in order for incriminating statements to be admitted into evidence. ${ }^{5}$ Although there are possible grounds for distinguishing police interrogation from administrative investigation and although the Court probably did not have administrative investigations in mind when it announced Escobedo ${ }^{6}$ it is the thesis of this comment that a consistent application of the rationale of Escobedo requires the extension of the sixth amendment right to counsel to the criminal investigations of the Internal Revenue Service ${ }^{7}$ and, perhaps, to those of other agencies as well.

S. 1663, 88th Cong., 2d Sess. (1964), and was not objected to by any person who testified in the hearings. See Hearings on Administrative Procedure Act Before Subcommittee on Administrative Practice and Procedure of the Senate Committee on the Judiciary, 88th Cong., 2d Sess. (1964). The bill failed to clear the committee because of other, more controversial features. Letter From Bernard Fensterwald, Jr., Chief Counsel, Senate Committee on the Judiciary, Subcommittee on Administrative Practice and Procedure, to The University of Chicago Law Review, April 26, 1965, on file in the Review office. The recommendation reappeared, however, in the 89th Congress in two bills: S. 1523, 89th Cong., 1st Sess. (1965), which is limited to this issue, and S. 1396, 89th Cong., 1st Sess. § 6(a) (1965), which is a bill revising the entire Administrative Procedure Act. But the American Bar Association's proposed revision of the APA restricted the right to counsel to those who are compelled to appear before an agency. S. 1879, 89th Cong., 1st Sess. \$ 1005(a) (1965). See generally Hearings on S. 1160, S. 1336, S. 1758 \& 1879 Before the Subcommittee on Administrative Practice and Procedure of the Senate Committee on the Judiciary, 89th Cong., 1st Sess. (1965).

5 See, e.g., Scanlon v. United States, 223 F.2d 382 (1st Cir. 1955). See generally BaLter, TAX FraUd AND Evasion § 5.4-6A (3d ed. 1963); LockHART, Kamisar \& Choper, op. cit. supra note 2, at 138-39 (1964); 10 MERTENS, LAW OF FEDERAL InCOME TAXATION § 55A.21, at 122-23, 128 (1964); Note, Constitutional Aspects of Federal Tax Investigations, 57 Colum. L. REv. 676, 683-85 (1957).

( Although it could be argued that police officers are administrative, rather than judicial or legislative, officials and that hence Escobedo obviously applies to all investigations of what are normally regarded as administrative agencies, Escobedo must be initially viewed in the context of a long line of cases dealing with police conduct towards suspects and defendants. The decision has been interpreted as an expression of exasperation with the failure of state courts and state legislatures adequately to regulate the police. Herman, The Supreme Court and Restrictions on Police Interrogation, 25 OHо ST. L.J. 449, 499 (1964); Packer, Policing the Police, The New Republic, Sept. 4, 1965, pp. 17, 18-19. It is also true that the Court has, without an express rationale, viewed the investigations of administrative agencies as a universe separate from the world of the police. See, e.g., United States v. Powell, 379 U.S. 48 (1964) (probable cause not necessary to obtain subpoena of tax records for tax years closed for all purposes except fraud); Abel v. United States, 362 U.S. 217 (1960) (permitted evidence seized during a search without a warrant and incident to an arrest pursuant to an administrative deportation to be used in a criminal prosecution); Frank v. Maryland, 359 U.S. 360 (1959) (upheld conviction and fine for refusal to permit city health inspector to inspect home for suspected rodent infestation without a warrant). See generally I DAvis, op. cit. supra note 4 , § 301 . In this comment administrative investigations are taken to be investigations by "a governmental authority, other than a court and other than a legislative body, which affects the rights of private parties either through adjudication or rule making." $I d$. $\S 1.01$, at 1 .

7 The IRS has been selected as the focus of the discussion because, besides the FBI, it 
In reaching its decision to extend the constitutional right to counse $^{8}$ to some pre-indictment proceedings, the Supreme Court in Escobedo formulated its holding quite narrowly:

We hold ... that where, as here, the investigation is no longer a general inquiry into an unsolved crime but has begun to focus on a particular suspect, the suspect has been taken into police custody, the police carry out a process of interrogations that lends itself to eliciting incriminating statements, the suspect has requested and been denied an opportunity to consult with his lawyer, and the police have not effectively warned him of his absolute constitutional right to remain silent, the accused has been denied "the Assistance of Counsel" in violation of the Sixth Amendment to the Constitution as "made obligatory upon the States by the Fourteenth Amendment ...."

Despite this narrow statement, the Court announced a rationale which seems to call for an expansion of the holding enunciated in Escobedo. ${ }^{10}$ Instead of speaking in terms of voluntary versus involuntary confessions, the opinion focuses on the right to counsel. According to the Court, the presence of counsel at pre-indictment interrogations is necessary in order to effectuate the individual's right to counsel at trial, ${ }^{11}$ which the Court recently discussed in Gideon $v$. Wainwright. ${ }^{12}$ Since the major purpose of requiring counsel at trial is

seeks to invoke criminal sanctions more often than any other federal administrative agency. Although almost all federal agencies administer statutes which have criminal provisions for their violation, some agencies in fact make little use of the criminal provisions. The Federal Aviation Agency and the Federal Communications Commission, for example, have each had less than ten criminal cases per year since 1958. See 1958-1964 ATr'y. GEN. ANN. REPS. The IRS, on the other hand, has had between 3,000 and 4,000 criminal liquor tax cases and about 1,000 criminal income tax cases per year since 1958. Ibid. The IRS directly affects more people than any other agency; almost anyone could be the subject of a tax investigation. See Application of House, 144 F. Supp. 95, 103 (N.D. Cal. 1956); Miller, Administrative Agency Intelligence-Gathering: An Appraisal of the Investigative Powers of the Internal Revenue Service, 6 B.C. IND. \& CoM. L. REv. 657, 664-66 (1965); Rogge, Inquisitions by Officials: A Study of Due Process Requirements in Administrative Investigations-1, 47 MINN. L. REv. 939, 964-70 (1963).

The IRS has taken the position that Escobedo does not apply to any of their investigations. See Letters From Mitchell Rogovin, Chief Counsel, Internal Revenue Service, Treasury Department, to The University of Chicago Law Review, May 6 \& 27, 1965, on file in the Review office.

8 "In all criminal prosecutions, the accused shall enjoy the right . . . to have the Assistance of Counsel for his defense." U.S. CoNst. amend. VI.

9378 U.S. 478, 490-91 (1964).

10 The expansiveness of the majority opinion was a major reason for the three vigorous dissenting opinions. See id. at 492-99.

$11 \mathrm{Id}$. at $486-90$.

12372 U.S. 335 (1963). 
to ensure that the defendant fully avails himself of his other constitutional rights, the right to counsel would be a "very hollow thing"13 if the individual were not apprised of his constitutional rights during the pretrial investigation and if the investigator were thus able to circumvent the constitutional protections by taking advantage of the individual's weakness, fear, or lack of legal advice. And according to some members of the Court, the presence of counsel at the interrogation also serves as a curb on police excesses and on the possibility of the investigator's falsification of the circumstances surrounding the accused's incriminating statements. ${ }^{14}$

This rationale covers those IRS investigations which undertake the detection of facts justifying the imposition of criminal sanctions. ${ }^{15}$ Since the taxpayer-defendant in a criminal tax case has the same procedural and constitutional rights after indictment as does the accused in a homicide or theft case, ${ }^{16}$ the concern of Escobedo for the effectuation of the right to counsel at a criminal trial by assuring that the individual has knowledge of his rights at the pre-indictment stages applies with full force to criminal tax proceedings. Moreover, in some criminal tax cases there is a question whether the agent misrepresented the purpose of his investigation or deceived or tricked the taxpayer into making statements about his financial situation or disclosing his financial records. As in the coerced confession cases, the admissibility of the evidence acquired during the investigation often turns on the conflicting testimony of the investigator and the person being investigated; the presence of counsel would provide an alternative to the necessity of relying too strenuously on the testimony of either the taxpayer or the revenue agent. ${ }^{17}$

13378 U.S. at 487 (citing In re Groban, 352 U.S. 330, 344 (1957) (Black, J., dissenting)).

14 Crooker v. California, 357 U.S. 433, 443 (1958) (Douglas, J., dissenting).

15 The plausibility of applying Escobedo to administrative investigations was suggested by Herman, supra note 6, at 475 \& $\mathrm{n} .154$ (1964); Comment, The Right to Counsel During Police Interrogation: The Aftermath of Escobedo, 53 CALIF. L. REv. 337, 345 \& n.50 (1965); Note, The Supreme Court, 1963 Term, 78 HARv. L. REv. 143, 222-23 (1964); Note, Escobedo in the Courts: Mray Anything You Say Be Held Against You?, 19 RuTcERS L. Rev. 111, 121 n.62 (1964); Comment, The Curious Confusion Surrounding Escobedo v. Illinois, 32 U. ChI. L. REv. 560, 571 n.54 (1965). But see Enker \& Elsen, supra note 3, at 75-79.

16 FED. R. CRIM. P. 1. "These rules govern the procedure in the courts of the United States and before United States commissioners in all criminal proceedings . . . ." See generally BALTER, op. cit. supra note 5, at \$\$ 5.4-1, 5.4-6; Lipton, The Taxpayer's Rights: Investigation of Tax Fraud Cases, 42 A.B.A.J. 325 (1956); Weiss, Self Incrimination and Income Tax Investigations, 42 Taxes 706 (1964); Note, Constitutional Aspects of Federal Tax Investigations, 57 Colum. L. Rev. 676 (1957).

17 See Application of Bodkin, 165 F. Supp. 25 (E.D.N.Y. 1958), cross-appeal dismissed, 266 F.2d 55 (2d Cir. 1959); United States v. Lipshitz, 132 F. Supp. 519 (E.D.N.Y. 1955); United States v. Wolrich, 129 F. Supp. 528 (S.D.N.Y. 1955); United States v. Guerrina, 112 F. Supp. 
However easily the rationale of Escobedo may be applied to IRS investigations, the application must also be consistent with the elements of the holding insofar as they were intended as limitations on the right to counsel. The elements which must be considered are custody, the purpose of the interrogation, focus, unsolved crime, denial of request for counsel, and failure to advise the accused of his constitutional rights.

The factor of custody is the most difficult obstacle to the extension of Escobedo. ${ }^{18}$ While police interrogations usually occur at police headquarters where the suspect is physically confined, IRS investigations usually take place in the taxpayer's home, place of business, or in an IRS office. The taxpayer is free to order the agents out of his home or business establishment and is free to leave the IRS office. In addition, because IRS agents carry no weapons, the element of physical coercion is largely absent. Hence, if the underlying concern in the police interrogation cases were solely the prevention or deterrence of police brutality or physical abuse of the accused, Escobedo would not cover IRS investigations. ${ }^{19}$ But the courts are concerned with more than physical abuse; they also eschew clever psychological stratagems ${ }^{20}$ and excessively persistent interrogators ${ }^{21}$ as a means by which incriminating statements are extracted from the suspect. Cases in which revenue agents obtained taxpayers' papers or documents by misrepresentations or fraudulent or misleading statements reveal that IRS agents are capable of the latter. ${ }^{22}$ In addition, although the taxpayer is not under physical confinement there is still a confrontation between an individual and a representative of the state who may invoke a statutory right to inspect records, documents, or premises. ${ }^{23}$ This assertion of the authority of the state may be such that the individual feels he must submit without question. ${ }^{24}$ The considerations underlying Escobedo would point, therefore, toward a

126 (E.D. Pa. 1953), modified, 126 F. Supp. 609 (E.D. Pa. 1955). Contra, United States v. Frank, 245 F.2d 284 (3d Cir.), cert. denied, 355 U.S. 819 (1957).

18 See Memorandum for the United States in Opposition, p. 3, Spomar v. United States, 380 U.S. 975 (1965); Letter From Mitchell Rogovin, May 6, 1956, supra note 7, at 7. See also Enker \& Elsen, supra note 3.

19 See Enker \& Elsen, supra note 3 , at 75.

20 E.g., Haynes v. Washington, 373 U.S. 503 (1963) (police told accused he could not call his wife until he cooperated); Lynumn v. Illinois, 372 U.S. 528 (1963) (police told female accused that her children would not be taken from her if she cooperated).

21 Spano v. New York, 360 U.S. 315 (1959); Leyra v. Denno, 347 U.S. 556 (1954); Harris v. South Carolina, 338 U.S. 68 (1949); Watts v. Indiana, 338 U.S. 49 (1949); Ashcraft v. Tennessee, 322 U.S. 143 (1944). See generally Comment, The Coerced Confession Cases in Search of a Rationale, 31 U. CHr. L. REv. 133 (1964).

22 See cases cited supra note 17.

23 E.g., INT. REv. CoDE of 1954, § 7602.

24 Cf. In re Groban, 352 U.S. 330, 341-42 (1957) (Black, J., dissenting). 
nontechnical notion of custody, ${ }^{25}$ because the advice of counsel may be needed just as much during subtle and hence more disarming interrogations $s^{2 b}$ as it is during those undertaken in police custody.

The factor of the interrogation's purpose is closely linked with the element of custody, for both are facets of the coercive nature of the investigation. The purpose of the interrogation in Escobedo, as described by the Court, was to elicit "incriminating statements," 27 "to get him to confess," 28 and "to elicit a confession." 29 But Escobedo cannot be limited to confessions, for in Escobedo there was no confession, but rather an admission. Thus, the purpose requirement is easily satisfied in IRS criminal investigations, because the purpose of the revenue agent's activities is to gather information which, if there should be a criminal prosecution, will be incriminating. Neither can Escobedo be limited to oral statements, since it has long been held that the privilege against self-incrimination applies to personal papers and documents, such as tax and financial records, which are often the most important evidence in a criminal tax prosecution. ${ }^{30}$

The requirement that the investigation be focused on a particular

25 One commentator has suggested: "A strict view of custody would exclude from the scope of the requirement of counsel cases in which the accused surely needed the 'guiding hand' of counsel.... [e.g.] [W] here a police officer calls at the home of a suspect and proceeds to ask a series of questions, intended to elicit incriminating responses[.] Although the suspect, not under arrest, is technically free to leave, he may feel constrained. He may believe... that any attempt to terminate the conversation will result in his arrest. It may be expected that the Court will not overlook these realities in favor of a formalistic rule based on a strict definition of "custody." "Comment, supra note 15, 53 CALIF. L. REv. at 359.

26 An experienced tax attorney described the techniques and approach of internal revenue agents as follows: "The agents are understandably circumspect in their questioning of the taxpayer. Early in their careers, they have learned that it is easier to catch flies with molasses than with vinegar. They do not wish to antagonize the taxpayer or alarm him unduly .... For all these reasons they are pleasant in their relationship with the taxpayer, they do not confront him with incriminating evidence, and he is often lulled into a false sense of security." Avakian, Rights and Remedies of Taxpayers Suspected of Fraud, 33 Taxes 878, 879-80 (1955).

27378 U.S. at 491 .

$28 I d$. at 485 .

29 Id. at 492.

30 Boyd v. United States, 116 U.S. 616 (1886). See generally Orfield, The Privilege Against Self-Incrimination in Federal Cases, 25 U. PrTT. L. REv. 503, 517-20 (1964). But the fifth amendment does not cover corporate records, required records, or disclosure of records when immunity is granted. These exceptions to the privilege have their greatest use in administrative law. See generally 1 Davis, op. cit. supra note 4, \$§ 3.07-3.09; Heckerling, Tax Fraud Investigations: Cooperative or Adversary Proceedings, 39 TAxes 807 (1961); Meltzer, Required Records, the McCarran Act, and the Privilege Against Self-Incrimination, 18 U. CHL. L. REv. 687 (1951); Note, Required Information and the Privilege Against Self-Incrimination, 65 Colum. L. REv. 681 (1965). 
individual, even if taken literally, ${ }^{31}$ presents no barrier to the extension of Escobedo to criminal tax investigations, for a tax investigation necessarily singles out an individual as its object. This, of course, might not be the case in other administrative investigations, such as those for securities fraud, which involve the interrogation of hundreds of people at regional agency offices. ${ }^{32}$

The statement in Escobedo that the investigation was an "inquiry into an unsolved crime" might be thought to provide a basis for distinction between police interrogations and administrative investigations. ${ }^{33}$ Unlike the homicide in Escobedo, no corpus delicti or public act exists prior to the initiation of a tax investigation, and hence knowledge of the existence of a crime is not obtained until the investigation has been completed. But this is a false distinction, for in ordinary criminal cases it is not known that there was a crime until a final judgment in the case is reached. For example, discovery of a corpse does not necessarily indicate the commission of murder. The jury may find that the person who caused the death of the person whose body was found acted in self defense and hence committed no crime. The most that can be said about the two types of investigations is that in most ordinary criminal investigations the possibility of the existence of a crime is greater than the same possibility in criminal tax cases. This hardly seems a reasonable justification for distinguishing between the two types of investigations. Assume, for simplification, that there are two variables in all criminal cases-a crime and a perpetrator. In the ordinary criminal case the unknown in the investigatory stage is the perpetrator, since there are reasonable grounds for thinking that a crime was committed. Escobedo seems to say that when there are reasonable grounds for thinking the identity of the perpetrator is no longer unknown, there is a sixth amendment right to counsel. In an administrative crime like tax fraud, on the other hand, the grounds for thinking that a crime was committed may be less than in the ordinary criminal investigation, and hence the crime might be regarded as the unknown. If the investigators find a crime, they have simultaneously found the perpetrator. ${ }^{34}$ Thus, when an IRS agent has reasonable grounds for suspecting that a crime has been committed, an individual and a crime are in fact linked together just as they are when the ordinary criminal investigation has focused on some-

31 See Herman, supra note 6 , at 474 .

32 See generally Enker \& Elsen, supra note 3, at 76.

33 See Letter From Mitchell Rogovin, May 6, 1965, supra note 7, at 7. See also Letter From Philip A. Loomis, Jr., General Counsel, Securities and Exchange Commission, to The University of Chicago Law Review, Aug. 23, 1965, on file in the Review office.

34 See Letter From Philip A. Loomis, Jr., supra note 33. 
one. In both situations the individual needs counsel to inform him of the privilege against self-incrimination.

Similar considerations apply to the factor of denial of a request for an attorney. If Mr. Justice Goldberg's mention of Escobedo's request to see his attorney is taken as the establishment of a necessary condition for holding inadmissible a statement made to a criminal investigator prior to arraignment or indictment, it might be academic whether Escobedo applies to IRS criminal investigations, because a reading of criminal tax cases fails to disclose instances of IRS agents refusing requests to consult with counsel. But the argument against making such a request a necessary condition in any case is persuasive. The purpose of providing counsel at the interrogation or investigation is to effectuate the right to counsel at trial by advising the accused of his rights. And the failure to request counsel is an indication that this advice is especially needed. ${ }^{35}$ Furthermore, to say that a request is necessary before the right to counsel attaches is in effect to argue that failure to request counsel is a waiver of the right. However, the classic case on waiver of the sixth amendment right to counsel at trial, Johnson $v$. Zerbst, ${ }^{36}$ which was cited with approval in Escobedo, ${ }^{37}$ discussed waiver as follows:

A waiver is ordinarily an intentional relinquishment or abandonment of a known right or privilege. ... [C]ourts [must] indulge every reasonable presumption against waiver of fundamental rights and ... we do not presume acquiescence in the loss of fundamental rights. ${ }^{38}$

Hence the failure of the suspect to request counsel is not necessarily a waiver ${ }^{39}$ This is especially pertinent in tax investigations, most of which aim at discovering tax crimes as well as assessing tax liability. The taxpayer's natural preoccupation with the latter tends to obscure the need for counsel to advise him as a suspect under criminal investigation and hence to negate any inference from the failure to request counsel that the suspect intended to waive his right to counsel. Escobedo further suggests that waiver must include knowledge of the legal

35 See generally Herman, supra note 6, at 475-76; Comment, supra note 15, 53 CALIF. L. Rev. at 360; Note, supra note 15, 19 Rutgers L. REv. at 126; Comment, supra note 15, 32 U. Chr. L. REv. at 574-78.

36304 U.S. 458 (1938).

37378 U.S. at 490 n.14.

38304 U.S. at $464-65$.

30 See generally Note, supra note 15, 78 HARv. L. REv. at 220-21 (1964); Comment, supra note 15, 32 U. CHI. L. REv. at 560. See also Comment, Waiver of the Right to Counsel in State Court Cases: The Effect of Gideon v. Wainwright, 31 U. CHr. L. REv. 591 (1964). 
significance of the response to a question by the investigator. ${ }^{40}$ Thus, although courts might distinguish Escobedo on the technical ground that the accused did not request counsel, an accurate reading of Escobedo would not elevate such a request to the level of a necessary condition.

Finally, in Escobedo the police did not warn the accused of his right to remain silent. This raises the problem whether a warning by the police of the accused's right to remain silent is sufficient to sustain the admissibility of any subsequent admission or confession of the accused. ${ }^{41}$ This question is, however, independent of any distinction between police and administrative investigations, for if it were the only problem in applying Escobedo to administrative investigations, the answer would affect only what type of warning by IRS agents would be required.

There thus appear to be no restrictions in the rationale or holding of Escobedo which would necessarily foreclose its application to administrative investigations. If its application is to be denied, other grounds must be sought. One ground certain to be invoked is precedent.

In In re Groban, ${ }^{42}$ a state fire marshal who was conducting an investigation into the causes of a fire at the petitioner's place of business subpoenaed him to appear as a witness. The petitioner, after his request for the assistance of his attorney was rejected by the fire marshal, was committed to jail for refusal to testify without the assistance of counsel. In a habeas corpus proceeding, the Supreme Court held that the fire marshal's action was no breach of fourteenth amendment due process because the investigation was not a "criminal prosecution." The Court analogized the fire marshal's investigation to that of a grand jury, where there is no right to counsel. It was immaterial in the majority's view that the testimony might form the basis for subsequent criminal charges.

Groban was held to be controlling in Anonymous $v$. Baker, ${ }^{43}$ which involved the claim to a right to counsel in a judicial inquiry into alleged unethical practices of attorneys. The defendants were private detectives

40 See generally Herman, supra note 6, at 477-81.

Another difference between the sixth amendment and the APA right to counsel is the standard for waiving the right. Since the statute does not require the agency to advise the person being investigated of his statutory right, the cases on the statutory right do not even mention waiver as a possible issue on the apparent assumption that an appearance without counsel is a waiver even though the witness was not apprised of the right. See Administrative Procedure Act, 60 Stat. 240 (1946), 5 U.S.C. § 1005(a) (1964).

41 See generally Herman, supra note 6, at 475 n.154, 477-78; Comment, supra note 15 , 53 Calif. L. Rev. at 345 \& n.50, 351, 355; Comment, supra note 15, 32 U. CHr. L. Rev. at 578-79.

42352 U.S. 330 (1957).

43360 U.S. 287 (1959). 
and investigators who were convicted for contempt of court for their refusal to answer questions unless their attorneys could be in the room with them. The record indicated that they were being investigated for possible criminal prosecution. The Supreme Court, affirming the convictions, rejected the claim to a constitutional right to counsel.

However, neither Groban nor Baker is precedent on the sixth amendment right to counsel. Both were decided before the fourteenth amendment was specifically held to include the sixth amendment right to counsel,44 and in both cases neither the person being investigated nor the majority of the Court considered the sixth amendment applicable. ${ }^{45}$ And even if the cases are regarded as sixth amendment cases, assigning dispositive precedential value to them is highly questionable since the dissenters in those cases became the majority in Escobedo, which advances much the same rationale as appears in the Groban and Baker dissents. ${ }^{46}$ It can justifiably be stated that whether Escobedo applies to administrative investigations is an unresolved question. ${ }^{47}$ The courts

44 Gideon v. Wainwright, 372 U.S. 395 (1963), overruling Betts v. Brady, 316 U.S. 455 (1942).

45 The appellant in Groban expressly disclaimed reliance on the sixth amendment via the fourteenth amendment because his case, he conceded, was not a "criminal prosecution" and because he was not then an "accused." Brief for Appellant, p. 8, In re Groban, 352 U.S. 380 (1957). The appellant in Baker did not mention the sixth amendment, although by quoting Mr. Justice Black's dissent in Groban and by attempting to distinguish Groban he approximated an argument that his case was a "criminal prosecution." Brief for Appellant, pp. 17-23, Anonymous v. Baker, 360 U.S. 287 (1959).

46 The dissenters argued that regardless of the label attached to the inquiry, a person has a sixth amendment right "to use legal counsel whenever he is compelled to give testimony to law enforcement officers which may be instrumental in his prosecution and conviction for a criminal offense." In re Groban, 352 U.S. 330, 344 (1957) (Black, J., dissenting). In such a situation the presence of counsel at the investigation helps effectuate the right to counsel at trial. Escobedo v. Illinois, 378 U.S. 478, 487-88 (1964); In re Groban, supra at 344 . Counsel may also prevent coercion and protect against subsequent falsification by the investigator. Id. at 341 .

See also Crooker v. California, 357 U.S. 433 (1958) and Cicenia v. Lagay, 357 U.S. 504 (1958), which held there was no constitutional right to counsel at pre-indictment interrogation. In both of these cases Mr. Chief Justice Warren and Justices Black and Douglas (and Brennan, J--in Crooker but not in Cicenia, in which he took no part) dissented and again subscribed to the position that there should be a constitutional right to counsel in police interrogations. Escobedo at least circumscribed and perhaps overruled both Crooker and Cicenia. See Escobedo v. Illinois, 378 U.S. at 492; Comment, supra note 15, 32 U. CHI. L. REV. at 560 .

47 There is no uniform government policy on whether Escobedo applies to the investigations of different agencies. See Letter From Norbert A. Schlei, Assistant Attomey General, Office of Legal Counsel, Department of Justice, to The University of Chicago Law Review, Sept. 3, 1965, on file in the Review office.

Some federal investigative agencies have taken no public position on the applicability of Escobedo to their investigations. See Letter From Joseph J. Saunders, Chicf, Public Counsel and Legislative Section, Antitrust Division, Department of Justice, to The University of Chicago Law Review, Sept. 9, 1965, on file in the Review office; Letter From J. Edgar 
have not examined the problem; post-Escobedo cases involving a claimed right to counsel in administrative investigations have either assumed Escobedo applied generally to administrative investigations and legitimately distinguished the case, ${ }^{48}$ expressly avoided the issue, ${ }^{49}$ or ignored the question altogether. ${ }^{50}$

Hoover, Director, Federal Bureau of Investigation, Department of Justice, to The University of Chicago Law Review, Aug. 18, 1965, on file in the Review office. But in testimony before the Senate Judiciary Committee's subcommittee which was considering amendments to the Administrative Procedure Act, the Justice Department advocated that the FBI be exempted from a statutory right to counsel in administrative investigations. See Hearings on S. 1160 , supra note 4, at 210. Although this recommendation might not have been based on a determination of the constitutional question, it does seem to conflict with Escobedo. See Statement of Professor Davis, id. at 188.

Several agencies have expressed the opinion that Escobedo applies to their criminal investigations. See Letter From Mr. John R. Enright, Acting Commissioner of Narcotics, to The University of Chicago Law Review, April 26, 1965, on file in the Review office; Letter From Hugo A. Ranta, Assistant General Counsel, Treasury Department (Secret Service), to The University of Chicago Law Review, April 28, 1965, on file in the Review office; Letter From Lawrence Fleishman, Deputy Commissioner, Bureau of Customs, Treasury Department, to The University of Chicago Law Review, April 8, 1965, on file in the Review office; Letter From Mr. Raymond F. Farrell, Commissioner, Immigration and Naturalization Service, Department of Justice, to The University of Chicago Law Review, Sept. 27, 1965, on file in the Review office. Whether Escobedo applies to investigations of postal inspectors is academic because postal inspectors advise persons of their right to counsel and of the privilege against self-incrimination. See Letter From H. B. Montague, Chief Inspector, Post Offce Department, to The University of Ghicago Law Review, April 21, 1965, on file in the Review office.

The IRS and the SEG, on the other hand, take the position that Escobedo does not apply to any of their investigations. See Letters From Mitchell Rogovin, supra note 7; Letter From Philip A. Loomis, Jr., supra note 33.

48 Irwin v. United States, 338 F.2d 770 (9th Cir. 1964), cert. denied, 381 U.S. 911 (1965). The court rejected the defendant's contention that Escobedo forbade the admission into evidence of materials obtained from the defendant by a postal inspector through the mails without the inspector's disclosing his identity and of testimony given to postal inspectors in the presence of defendant's counsel.

49 H. Hentz \& Co. v. Lefkowitz, 22 App. Div. 2d 475, 256 N.Y.S.2d 724, aff'd without opinion, 15 N.Y.2d 958, 207 N.E.2d 519, 259 N.Y.S.2d 847 (1965). Here the state attorney general subpoenaed a witness in an investigation of alleged fraudulent practices in the commodities markets. The witness appeared with an attorney who had represented three other witnesses in the same investigation. The attorney general refused to conduct the investigation with that particular attorney present, and the witness refused to testify. The trial court granted the witness' suit to enjoin the investigation until he was allowed the advice of the particular attorney. The Appellate Division and the Court of Appeals affirmed.

The Appellate Division rested on the ground that since the regular practice of the attorney general was to permit any witness to have counsel, the attorney general could not now prevent a witness from relying on a particular attorney. In a footnote the court stated, "Whether Escobedo . . . will have any impact on the continued vitality of Groban remains to be determined." Id. at 725-26 n.l. The court referred to Enker \& Elsen's discussion of this question. See note 3 supra.

50 United States v. Steel, 238 F. Supp. 575 (S.D.N.Y. 1965) (SEC investigation into alleged fraud; held no sixth amendment right to counsel without citing or discussing Escobedo); 
An example of this judicial treatment of the problem is United States v. Spomar. ${ }^{51}$ The defendant taxpayer was convicted of criminal tax fraud, largely on the basis of testimony and evidence he gave to special agents. The special agents, in conformity with IRS practice, had not advised the taxpayer of his privilege against self-incrimination, his right to counsel, or the possibility of criminal prosecution; they merely identified themselves as special agents. On appeal the defendant contended that the evidence and testimony he gave to the special agents was inadmissible, because he had not known of his right to withhold the information. Escobedo, although relied upon by the defendant, was not cited for the proposition that there was an abridgement of his sixth amendment right to counsel. ${ }^{52}$ Instead the defendant argued that Escobedo established "that Fifth Amendment rights cannot be given up by uninformed defendants." 53 Without citing or discussing Escobedo, the Seventh Gircuit affirmed the conviction. The court rested on preEscobedo cases which held that revenue agents have no duty to advise the taxpayer of the possibility of criminal prosecution or of the privilege against self-incrimination and that absent misrepresentation, fraud, or deceit by the agents, any testimony or evidence given by the taxpayer is admissible. ${ }^{54}$

Thus, precedent does not stand in the way of extending Escobedo to tax investigations, and the only remaining argument against extension is that of administrative efficiency.55 Giving the taxpayer

Dinnen v. State, 168 So. 2d 703 (Fla. Dist. Ct. App. 1964) (county solicitor's investigation into possible criminal violations; Groban found controlling, Escobedo not argued or cited). 51339 F.2d 941 (7th Cir.), cert. denied, 380 U.S. 975 (1965).

52 See Brief for Defendant-Appellant, pp. 19-20, United States v. Spomar, 339 F.2d 941 (7th Cir. 1965). See also Brief for Petitioner, pp. 9-10, 380 U.S. 975 (1965).

53 Brief for Defendant-Appellant, p. 19, supra note 52.

54 The court tacitly adopted the argument of the Government's brief, which did not cite or discuss Escobedo. See Brief for Appellee, pp. 3-7, United States v. Spomar, 339 F.2d 941 (7th Cir. 1965). In opposing the petition for certiorari, however, the Government argued that Escobedo was distinguishable on the basis of custody and denial of request to consult with counsel. See Memorandum for the United States in Opposition, p. 3, 380 U.S. 975 (1965.)

55 Other possible objections to the application of Escobedo are not substantial. The distinction between malum in se and malum prohibitum might be invoked to argue that only traditional crimes, malum in se, are regarded as morally reprehensible and that only convictions for these crimes voice the community's moral outrage. The requirement of counsel would, under this argument, be necessary only for investigations of traditional crimes. The recent regulatory offenses, on the other hand, are not morally blameworthy and hence do not need the scrupulous safeguards in the guilt-determining process. But one of the desired effects of the new offenses is the creation of new objects of moral disapproval. In addition, the usefulness and validity of the distinction have been subjects of much debate. See generally Paulsen \& Kadish, Criminal Law and Its Processes 238-43 (1962); Ball \& Friedman, The Use of Criminal Sanctions in the Enforcement of Economic Legislation: A Sociological View, 17 Stan. L. REv. 197 (1965); Hart, The Aims of the Criminal 
notice of his rights and of the possibility of criminal prosecution would, it might be argued, increase dilatory action by taxpayers, increase the number of cases in which judicial enforcement of a subpoena is sought by the IRS, ${ }^{56}$ and increase the number of the more difficult and timeconsuming prosecutions based on the net worth, rather than the records, of the taxpayer. ${ }^{57}$ The resulting prolongation of each investigation and the greater difficulty of proof would create an administrative burden which due to sheer volume would be intolerable. But similar arguments of enforced delay in the investigatory process and of administrative burden were rejected in the police interrogation cases despite the social need for speedy apprehension of the murderer and thief. ${ }^{58}$ Rejection of the argument in tax cases would seem to follow, a fortiori, since

Law, 23 LAw \& Contemp. Prob. 401 (1958); Kadish, Some Observations on the Use of Criminal Sanctions in Enforcing Economic Regulations, 30 U. CHI. L. REv. 423 (1963).

Neither can different rules for the two types of investigations be justified by the difference in interests affected by the offenses. In ordinary crimes society's interest is the protection of the individual's body and property and hence the security and stability of the society. The interests affected by tax crimes, on the other hand, are the maintenance of the government's revenue, of equity between taxpayers, and of taxpayers' morale. The interests behind the two groups of crimes are undeniably important; indeed, that is why criminal sanctions are provided to protect them. But if the courts are highly protective of the rights of the suspect of an ordinary crime, it would seem that the courts should, a fortiori, be as concerned about the person accused of an administrative crime. See Hinchcliffe v. Clarke, 230 F. Supp. 91, 97, 109 (N.D. Ohio 1963).

Nor can the distinction rest on the nature of the penalty, for many administrative crimes are felonies punishable by fine, imprisonment for more than one year, or both. See, e.g., INT. REv. CODE OF 1954, \$\$ 7201-40.

Another conceivable distinction between the two types of offenses is the supposed difference in the character of the average offender. But such a difference should not be dispositive because it runs counter to the policy of regarding criminal defendants individually. And even though there may be differences in the education and intelligence of the average suspect in the two types of crimes, the suspect in the administrative investigation may be just as vulnerable as is the accused in a police interrogation. Since an administrative investigation can terminate in a number of different ways-criminal liability, civil liability, cease and desist orders-the person who is being investigated may not receive the warning of possible criminal liability that is inherent in a police interrogation about the circumstances of a homicide. Furthermore, even though the individual in an administrative investigation may be more intelligent than the defendant in ordinary criminal cases, so long as he is a layman he "needs the guiding hand of counsel" in order to exercise his rights effectively or to waive them intelligently. $C f$. Gideon v. Wainwright, 372 U.S. 335 (1963).

56 See, e.g., United States v. Powell, 379 U.S. 48 (1964), where the taxpayer refused to comply with a subpoena, forcing the IRS to seek judicial enforcement: The issue was whether the IRS had to show probable cause to obtain enforcement of a subpoena of records for tax years closed for all purposes except fraud. The Court's primary reason for holding probable cause unnecessary, was because it would increase dilatory actions by taxpayers and thereby work an administrative burden on the agency.

- 57 See generally Balter, TAx Fraud and Evasion § 3.3-2 (3d ed. 1963); Avakian, Rights and Remedies of Taxpayers Suspected of Fraud, 33 TAXES 878 (1955).

" 58 Escobedo v. Illinois, 378 U.S. 478, 488 (1964). 
the social interest in fast apprehension is not so pressing. Besides, there are several grounds for believing that the burden on the IRS resulting from a constitutional right to counsel might not be so heavy. Cooperation with the revenue agent in determining tax liability will often be in the taxpayer's interest because it reduces the expenses of contesting the issue of tax law, eliminates questions of fact, and avoids antagonizing the agent; ${ }^{59}$ in the ordinary criminal case, on the other hand, there is no similar incentive to cooperate. Even when there is noncooperation by the taxpayer in the regular audit, the IRS can issue an administrative subpoena of the taxpayer's records, since the taxpayer cannot withhold all records, but only those which tend to incriminate him. ${ }^{60}$ Nor would criminal prosecution be impossible, since third parties like banks and employers usually have records relevant to a taxpayer's tax liability. ${ }^{61}$

In summary, the rationale of Escobedo covers IRS criminal tax investigations, and neither the elements of the holding in Escobedo, precedent, nor considerations of administrative efficiency compel a different result. It must, therefore, be determined when the sixth amendment right to counsel attaches in tax investigations. There are three possible stages in the tax investigation when this might occurwhen the special agent contacts the taxpayer, when the primary purpose of the investigation becomes criminal detection, or when the ordinary revenue agent first approaches the taxpayer.

The latest that the right to counsel might attach is when the special agent contacts the taxpayer because his primary, if not exclusive, function is investigation of alleged tax crimes. ${ }^{62}$ But the determination of the time the right attaches should not depend on the title and function of the official investigator. In most agencies there are no special criminal

\footnotetext{
59 See generally BALTER, op. cit. supra note 57, \$§ 6.1-6.4-1.

60 See generally Weiss, Self Incrimination and Income Tax Investigations, 42 TAxes 706 (1964).

61 See generally BALTER, op. cit. supra note 57, \$§ 5.3-5-5.3-10. Even if it is thought that the extension of Escobedo to IRS investigations would impair criminal tax prosecutions, it is not necessarily true that there should be no extension. "The inability of the Bureau to audit all returns increases the importance of retaining the criminal penalties, pushing for somewhat more severe sentences and advertising them to the general public by a substantial number of prosecutions each year." Lyon, The Crime of Income Tax Fraud: Its Present Status and Function, 53 CoLuM. L. Rev. 476, 480 (1953). But this reason for having criminal sanctions to help enforce the tax laws should be of decreasing importance with the greater use of computers by the IRS. See [July 1962-June 1963] CoMn'R INT. REv. ANN. Rep. 15, 43-44; [July 1963-June 1964] CoMm'r INT. Rev. ANN. REp. 12-13, 37-38. Furthermore, it has been suggested that if apprising accuseds and defendants of their rights presents administrative problems, legislatures should reexamine what society has made criminal and reduce the number of crimes. See Packer, Two Models of the Criminal Process, 113 U. PA. L. REV. 1, 67-68 (1964).
}

62 See BALTER, op. cit. supra note 57, \& 3.3-2. 
investigators; even in the tax field the ordinary internal revenue agent sometimes continues his examination after he has decided to recommend a criminal investigation. ${ }^{63}$ Furthermore, to link the right to counsel to the official function of the agent would encourage agencies to avoid using specialized criminal investigators, and "a person should be entitled to the same constitutional rights regardless of the official title or technical description of the government agent who appears to interview him." 64

Another point at which the sixth amendment right might attach is when the primary purpose of the investigation is criminal detection. An objection to this position, voiced in some cases, is that "the purpose of the investigation is a too illusory concept to form a rational and practical basis for a distinction." 65 The assumption of this criticism seems to be that the test would be subjective-Did the agent, in fact, at this point of time think there should be a criminal investigation? But here as elsewhere in the law a reasonable man standard might be used: Would a reasonable man have thought that at a particular point in the investigation the evidence called for a criminal inquiry? This approach would be similar to that adopted by the Supreme Court in Escobedo, and by the California Supreme Court, ${ }^{66}$ on the problem of "focus;" the courts suggested an objective approach whereby "focus" is measured by the weight of the evidence available to the police at different points of time in the investigation. But even if a reasonable man standard were adopted, the primary purpose test would create a stress point in the system and would thus result in an administrative and judicial burden.

In fact, however, every tax investigation has a twofold purposediscovery of tax liability and discovery of criminal violations-and facts uncovered in the early stages of an investigation may become crucial in a subsequent criminal prosecution. ${ }^{67}$ Thus, a consistent application of

63 See Balter, op. cit. supra note 57, § 3.3-2, at 3-14 n.24.

64 United States v. Remolif, 227 F. Supp. 420,424 (D. Nev. 1964).

65 Ibid.

66 People v. Dorado, 394 P.2d 952, 40 Cal. Rptr. 264 (1964), aff'd on rehearing, 398 P.2d 361, 42 Cal. Rptr. 169 (1965), cert. denied, 85 Sup. Ct. 1793 (1965). See generally Enker \&: Elsen, Counsel for the Suspect, 49 Mins. L. Rev. 47, 70 (1964).

67 If the suggested analysis is generally applied to other administrative investigations a problem arises as to whether the sixth amendment right to counsel applies to all agencies and all investigations. The problem can be avoided in any consideration of the IRS on the ground that if the right is to exist in the investigations of any agency it would surely be the IRS. As a tentative hypothesis, the sixth amendment right to counsel would not apply to investigations of agencies like the Civil Rights Commission which have no authority for enforcement of a statute or regulations. Cf. Hannah v. Larche, 363 U.S. 420 (1960). But it would apply to agencies which have authority for enforcement of a statute with criminal provisions.

It might, however, be decided that the early stages of tax investigations are more ac- 
Escobedo would call for the sixth amendment right to counsel to attach whenever any revenue agent contacts the taxpayer.

Implementation of this new constitutional requirement would necessitate several changes in tax investigations. ${ }^{68}$ The taxpayer would have to be advised of his constitutional right to counsel or at least of the privilege against self-incrimination whenever any agent, regular or special, came to inspect his tax records. The ordinary agent would have to inform the taxpayer of the theoretical possibility of criminal prosecution at the initiation of the whole investigatory process. This would ensure fairness to the taxpayer and would maximize the deterrent value of the criminal sanctions; although the majority of taxpayers who are subjected to an ordinary audit are not made the object of a criminal investigation, they would thus be made aware of the existence of criminal sanctions and of their potential use. ${ }^{69}$ The preferable way to advise the taxpayer would be to send a letter ${ }^{70}$ prior to the agent's fixing

curately classified as civil investigations and that, therefore, the sixth amendment right to counsel would not apply until the primary purpose of the investigation had become criminal detection. Even so, because the findings made in these early stages may be crucial in subsequent criminal tax prosecutions, a taxpayer needs to know from the outset what rights he possesses in order to exercise them effectively or to waive them intelligently. Hence, it would seem only fair that a right to counsel attach at the commencement of a tax investigation, and the notions of fairness embodied in the due process clause of the fifth amendment could provide the basis for recognizing such a right.

Here again, however, In re Groban, 352 U.S. 330 (1957), and Anonymous v. Baker, 360 U.S. 287 (1959), are encountered as precedential obstacles. But their present-day vitality has been undermined by Escobedo, and thus they present no problem. Apart from Groban and Baker, cases which have held there is no fifth amendment due process right to counsel in administrative investigations may be distinguished from tax investigations on the ground that in those cases the agencies had no responsibility for investigating for possible criminal violations, whereas the IRS has such authority. United States ex rel. Bilokumsky v. Tod, 263 U.S. 149 (1923); Lou Wah Suey v. Backus, 225 U.S. 460 (1912) (pre-deportation investigations). But see Kennedy v. Mendoza-Martinez, 372 U.S. 144 (1963) (deportation regarded as punishment and hence the criminal jury trial requirement of the sixth amendment had to be satisfied). See generally Comment, The Concept of Punitive Legislation and the Sixth Amendment: A New Look at Kennedy v. Mendoza-Martinez, 32 U. CHI. L. REv. 290 (1965). The only case which cannot be distinguished on this ground is a lower court holding that there was no fifth amendment right to counsel in OPA investigations, as one of the sanctions for violations of OPA-administered statutes was a criminal penalty. Bowles v. Baer, 142 F.2d 787 (7th Cir. 1944).

68 See also Miller, Administrative Agency Intelligence-Gathering: An Appraisal of the Investigative Powers of the Internal Revenue Service, 6 B.C. IND. \& CoM. L. REv. 657, 71015 (1965), for other suggested changes in IRS procedure to accord the taxpayer fairer treatment.

60 It might be argued that informing all taxpayers, who are investigated, of the possibility of criminal punishment would unnecessarily frighten the taxpayer. See Miller, supra note 68 , at 714 . But the letter suggested in note 70 infra should dampen those fears.

70 This is the procedure in income tax fraud cases under Wisconsin law: "The taxpayer is notified by letter that a special agent is conducting an investigation before he is requested to furnish any records or information." Lipton \& Petrie, Wisconsin Criminal Tax Fraud 
an appointment and to have the agent inquire whether the taxpayer had received, read, and understood the contents of the letter. The letter would eliminate the problem of making certain that all the agents are in fact giving the correct advice and the problem of proof when the issue of waiver is raised in court. In addition, to ensure that the taxpayer is not misled by the course of the investigation, the ordinary internal revenue agent should also be required to inform the taxpayer whenever the purpose of the investigation shifts to criminal detection, and the special agent should advise the taxpayer of his rights and of the function of the special agent.

All of these changes should increase the taxpayer's respect for the fairness of the enforcement of the income tax laws and should reduce the number of cases in which the taxpayer moves to suppress evidence gained during the agent's examination. The taxpayer's right to counsel would be more of a reality and would help improve the adversary nature of the proceeding. The criminal enforcement of the tax law should be limited by the same safeguards for the person on whom the investigation has focused which have been deemed necessary in the ordinary criminal law.

Problems, 48 MARQ. L. REv. 1, 7 (1964). A federal court has suggested that this be done in federal cases: "It would of course be far preferable, so that it may be made certain that the choice of the taxpayer be an informed choice, that written warning be given when the civil audit is suspended as such, and the investigation becomes one to determine whether criminal or civil fraud penalties should be sought by the government. This would not only protect the taxpayer's constitutional rights, but also obviate much of the delay in tax cases caused by such motions as the one [motion to suppress evidence] before us." Grant v. United States, $291 \mathrm{~F} .2 \mathrm{~d}$ 227, 228 (2d Cir. 1961), judgment vacated and remanded to dimiss appeal, 369 U.S. 401 (1962). See also Miller, supra note 68, at 710. Such a notice might take the following form:

Dear Taxpayer:

As a part of our continuing effort to ensure that everyone pays his fair share of federal income taxes, we are sending agent .... to audit your tax returns for the tax years ... to .... The purpose of this audit is to determine if your reported tax liability for the above years is correct.

We also remind you that the law provides criminal penalties for wilful attempt to evade taxes or for wilfully filing a false and fraudulent return. Although most of our regular audits terminate with either no or some additional assessment of taxes, a few audits develop into investigations for tax crimes. The agent will inform you if he thinks there should be a criminal investigation of your returns.

You have the constitutional right to the assistance of an attorney or accountant for the audit. The agent has a right by Act of Congress to inspect the papers and documents of any taxpayer relating to tax liability, but you have the right under the fifth amendment to the United States Constitution to refuse to answer any questions or to produce documents if either would tend to incriminate you. The appropriateness of the taxpayer's use of the privilege will, however, have to be determined by a United States District Court.

Agent ... will call to set an appointment for the audit. We assure you that the Internal Revenue Service and its agents will be fair with you during the examination. 